\title{
Spatial and Temporal Effects on Switchgrass Stands and Yield in the Great Plains
}

\author{
M. R. Schmer • R. B. Mitchell • K. P. Vogel • \\ W. H. Schacht • D.B. Marx
}

Published online: 20 August 2009

(C) US Government 2009

\begin{abstract}
Switchgrass (Panicum virgatum L.) is being developed into a perennial, herbaceous, cellulosic feedstock crop for use in temperate regions of the USA. Information on spatial and temporal variation for stands and biomass yield among and within fields in large agroecoregions is not available. Spatial and temporal variation information is needed to model feedstock availability for biorefineries. In this 5-yr study, the spatial and temporal variation for biomass yield and stands was determined among and within 10 fields located in North Dakota, South Dakota, and Nebraska. Switchgrass fields were managed for bioenergy from 2000 to 2004 for the Nebraska locations and 2001 to 2005 for the South Dakota and North Dakota locations. A global positioning system (GPS) receiver was used to repeatedly measure within field quadrat sites for switchgrass stands using frequency grid $\left(2.25 \mathrm{~m}^{2}\right)$ measurements in June for five growing seasons. Sixteen quadrat
\end{abstract}

M. R. Schmer $(\bowtie)$

USDA-ARS, Northern Great Plains Research Laboratory,

P.O. Box 459, Mandan, ND 58554, USA

e-mail: marty.schmer@ars.usda.gov

R. B. Mitchell • K. P. Vogel

USDA-ARS, Grain, Forage, and Bioenergy Research Unit, University of Nebraska,

P.O. Box 830737, Lincoln, NE 68583, USA

W. H. Schacht

Department of Agronomy and Horticulture,

University of Nebraska-Lincoln,

377L Plant Science Hall,

Lincoln, NE 68583-0915, USA

D. Marx

Department of Statistics, University of Nebraska-Lincoln, 340 Hardin Hall North,

Lincoln, NE 68583-0963, USA $\left(\geq 1 \mathrm{~m}^{2}\right.$ ) yield samples were taken post-killing frost in the establishment year and in August in subsequent years at each location. Topographic within field effects on switchgrass stand frequency and biomass yields were largely insignificant. Stands tended to increase from establishment year to year 3 and then begin to plateau. Weather factors, which were the principal source of temporal variation, were more important in switchgrass yield variation than on switchgrass stand frequencies. Temporal standard deviations for yield were higher on quadrat sites with higher than average field means while temporal standard deviations were smaller in quadrat sites that had lower than average field means at six locations. In the Northern Great Plains agroecoregion, there is greater temporal and spatial variation for switchgrass biomass yields among fields than within fields. Results indicate that modeling feedstock availability for a biorefinery can be based on field scale yields.

Keywords Switchgrass · Great Plains · Bioenergy · On-farm trials $\cdot$ Spatial variation $\cdot$ Temporal variation

\section{Introduction}

Corn (Zea mays L.) grain is the primary ethanol source for the United States, but grain supply limitations and federal mandates will limit grain ethanol expansion to 57 billion $\mathrm{L} \mathrm{yr}^{-1}$ by 2015 [27]. Alternative biofuel sources will be required to further increase domestic ethanol supply in the United States. Utilization of perennial herbaceous crops as biofuel sources has been proposed to enhance ecological services such as soil conservation and water quality over annual cropping systems [14]. Switchgrass (Panicum virgatum $\mathrm{L}$.) is being evaluated as a cellulosic ethanol crop 
in the Great Plains because of favorable feedstock costs [23], soil carbon sequestration [17], and significant net energy benefits when grown on marginal lands [24].

Current research on switchgrass biomass production has largely evaluated switchgrass adaptability on small-scale plots in varying environments $[9,10]$. Landscape-scale information on switchgrass yield variation is limited, but suggests that spatial patterns affect biomass yield [29]. An estimated 3-21 million ha of existing agricultural land in the U.S. is projected to be converted to perennial grasses for bioenergy based on theoretical market price [20]. Agricultural land for perennial grass bioenergy systems will likely come from marginal land currently in crop production and idle land currently enrolled in the conservation reserve program (CRP) [11, 20, 34].

Solar radiation, temperature, water, and nutrient uptake efficiency all contribute to feedstock yield. Previous research has shown that within field elevation had a negative correlation with corn yields, likely caused by water availability [15]. Slope was identified as a yieldlimiting factor for corn and soybean (Glycine max L.) fields in Michigan [13]. On a prairie ecosystem, evapotranspiration and soil temperature varied by aspect position [2]. Topography had the largest effect on corn yield in extreme weather conditions [15]. Lowland prairie sites produced more aboveground net primary production than upland sites in a $10 \mathrm{yr}$ tallgrass prairie ecosystem study with water stress on upland sites being suggested as the main reason for lower productivity [1]. Variation of net primary production in tallgrass prairie systems is affected by light, water, and nutrient availability caused by topography, fire history, and climatic conditions [5]. Unlike annual cropping systems and established grassland systems, the temporal effects for recently established herbaceous perennial crops will be affected by both weather conditions and stand development. Switchgrass, in general, does not reach full yield potential until one to two years after establishment [32].

Information on temporal and spatial variability is needed for several reasons. Biomass refineries are expected to have four to five times higher capital costs than similar sized grain ethanol plants based on first generation biomass refining technology [36]. A reliable feedstock supply will be essential in maintaining stable operational costs. The variation that can occur in biomass yields due to spatial and temporal variation needs to be known in order to obtain reliable estimates of feedstock supply areas for biorefineries and to reduce producer's risk. Information on spatial and temporal variation can be used to develop sampling strategies to obtain estimates of feedstock supply within production years. The first objective of the study was to quantify temporal variation and stand development on switchgrass stand frequency and yield over time from establishment to full maturity on large switchgrass fields in the Great Plains. The second main objective was to evaluate spatial and temporal effects on switchgrass stand frequency and yield by location.

\section{Materials and Methods}

The study was conducted on farms in North Dakota (2 fields), South Dakota (4 fields), and Nebraska (4 fields) which also were used for economics [23], soil carbon sequestration [17] and net energy analyses [24] of switchgrass grown and managed as a biomass energy crop. Farms are identified by the nearest town (Fig. 1). The 10 farms were located in areas where previous economic model analyses indicated switchgrass grown as a biomass energy crop would be economically feasible [33]. Fields were chosen based on characteristics of the region and qualifications in CRP. U.S. Department of Agriculture Natural Resources Conservation Service (USDA-NRCS) staff from Nebraska, South Dakota, and North Dakota assisted with identifying potential cooperators and field sites. Nebraska locations were planted in 2000. The Atkinson, NE location was replanted in 2001 because of stand failure caused by drought. The South Dakota and North Dakota locations

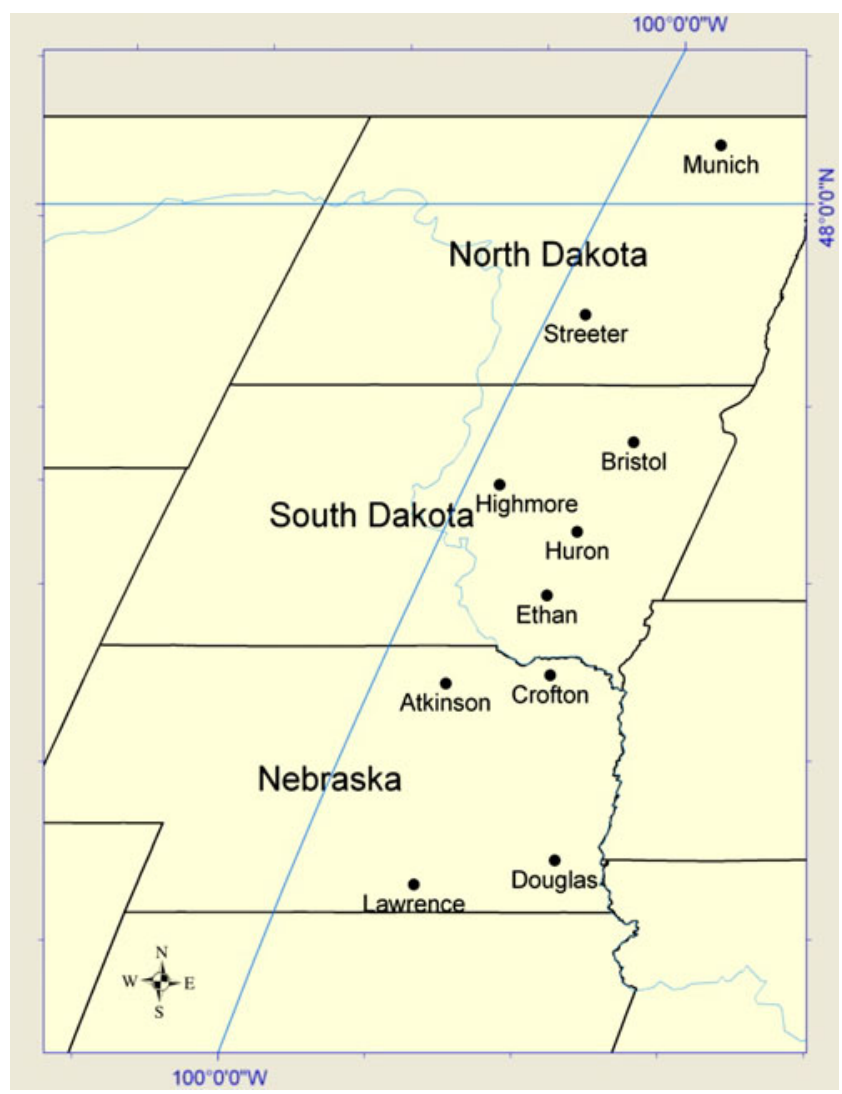

Fig. 1 Location of switchgrass fields evaluated for stand frequency and yield variation in the Northern Great Plains 
were planted in 2001. Field size ranged from 3 to 9.5 ha with an average of 6.7 ha. Farm cooperators managed all aspects of switchgrass production and harvest except that the Nebraska fields were planted by USDA Agricultural Research Service (ARS) Lincoln Grain, Forage, and Bioenergy Research Unit personnel.

A general set of recommended management practices based on previous small plot research was given to all farm cooperators [32]. These management practices detailed seedbed preparation, planting depth, planting dates, herbicide use, and harvesting dates. Seeding rates were 322 pure live seed (PLS) $\mathrm{m}^{-2}$. Cultivars selected for each field were based on prior research within respective geographical regions. Switchgrass cultivars used in the study were 'Cave-in-Rock', 'Trailblazer', 'Shawnee', and 'Sunburst'. The selected cultivars were primarily developed for pastures. Soil descriptions, previous cropping history and field size by location were described previously by Schmer et al [25].

Soil samples were taken on each field before switchgrass establishment to assess soil fertility [17]. No fertilizer was applied in the planting (establishment) year. Nitrogen rates varied in post-establishment years by location based on potential biomass yield for each respective location, cooperator judgment, and weather conditions (Table 1). Nitrogen rates were based on previous research in the Central Plains which showed that at current switchgrass yield levels, approximately 10 to $12 \mathrm{~kg} \mathrm{~N} \mathrm{ha}^{-1}$ is required for each megagram per hectare of expected biomass yield [31]. Nitrogen applications occurred in late spring. Weather data for each field were collected from nearby meteorological stations (Table 2).

Switchgrass stand frequencies were made using a 0.75 $\mathrm{m} \times 0.75-\mathrm{m}$ frequency grid in early June from 2000

Table 1 Nitrogen application rates of switchgrass fields managed for bioenergy production in the Northern Plains

\begin{tabular}{|c|c|c|c|c|}
\hline \multicolumn{5}{|l|}{ Harvest Year } \\
\hline $\begin{array}{l}\text { Location } \\
\text { Nitrogen } \mathrm{kg} \mathrm{ha}^{-1}\end{array}$ & 2 & 3 & 4 & 5 \\
\hline Munich, ND & 67 & 118 & 112 & 52 \\
\hline Streeter, ND & 0 & 52 & 112 & 112 \\
\hline Bristol, SD & 212 & 76 & 108 & 0 \\
\hline Highmore, SD & 0 & 67 & 56 & 0 \\
\hline Huron, SD & 0 & 34 & 52 & 68 \\
\hline Ethan, SD & 112 & 140 & 52 & 112 \\
\hline Crofton, NE & 22 & 112 & 50 & 52 \\
\hline Atkinson, NE & 67 & 75 & 86 & - \\
\hline Douglas, NE & 99 & 112 & 82 & 115 \\
\hline Lawrence, NE & 84 & 110 & 90 & 90 \\
\hline
\end{tabular}

through 2005 [30]. Sample areas were randomly chosen by stratification based on cultivar and/or topography within each field. A 12-channel GPS receiver (Lowrance Globalmap 1001; Catoosa, $\mathrm{OK}^{1}$ ) was used to georeference each quadrat site within each switchgrass field. The presence or absence of switchgrass tillers in each of the 25-grid cells were recorded and flipped end-to-end for a total of 100 cells per quadrat site. A total of 12 quadrat sites were sampled at each switchgrass field for stand frequency in 2000 and 2001. In 2002, 16 quadrat sites were measured for stand frequency and 25 quadrat sites were measured from 2003 through 2005 at each switchgrass field. The GPS derived quadrat sites were repeatedly measured for stand frequency and clipped quadrat yields. Biomass yields were estimated at 16 quadrat sites within a field using a $1-\mathrm{m} \times 1-\mathrm{m}$ quadrat in 2000 and a $0.3-\mathrm{m} \times$ 3.66-m frame $\left(1.1-\mathrm{m}^{2}\right)$ in 2001 through 2006 at the plant maturity stage of R1 to R5 [21] (panicle fully emerged from boot to post-anthesis) or after a killing frost. Yield quadrat sizes and sample numbers were based on previous standing crop results to reduce sampling variance and increase sampling efficiency [6]. Total plant biomass within the frame was clipped to a $10-\mathrm{cm}$ stubble height and weighed with a portable electronic scale (Intercomp CS750, Minneapolis, MN). A subsample was dried at $55^{\circ} \mathrm{C}$ for $48 \mathrm{hr}$ to determine dry matter yield.

Following quadrat sampling, fields were mechanically harvested and baled by cooperators. Most cooperators chose to harvest at emerged inflorescence to postanthesis (early to mid-August) in post-establishment years, except for the Bristol and Munich locations, which were harvested after a killing frost. Six locations were mechanically harvested in the establishment year while the Lawrence, Crofton, and Douglas locations were burned the following spring. The establishment year biomass for the Ethan location was neither removed nor burned the following spring but rather left due to lodging and subsequent switchgrass early spring growth in 2002.

To determine topographic values, digital elevation models [28] were converted to slope, aspect, elevation, and curvature values using 3D analyst in ArcGIS (ESRI Corp., Redlands, CA). Aspect was transformed to north and south facing exposures by taking the absolute value of aspect in degrees-180. Negative curvatures correspond to concave surfaces while positive curvatures correspond to convex surfaces.

\footnotetext{
${ }^{1}$ Trade and company names or commercial products is solely for the purpose of providing specific information and does not imply recommendation of endorsement by the U.S. Department of Agriculture.
} 
Table 2 Mean annual precipitation by location for switchgrass fields managed for bioenergy production in the Northern Plains

\begin{tabular}{|c|c|c|c|c|c|c|c|c|c|c|}
\hline & Munich & Streeter & Bristol & Highmore & Huron & Ethan & Crofton & Atkinson & Douglas & Lawrence \\
\hline Year & \multicolumn{10}{|c|}{ Precipitation (mm) } \\
\hline 2000 & - & - & - & - & - & - & 605 & 426 & 658 & 678 \\
\hline 2001 & 458 & 396 & 414 & 436 & 680 & 642 & 825 & 716 & 965 & 760 \\
\hline 2002 & 516 & 414 & 427 & 293 & 378 & 526 & 553 & 344 & 548 & 612 \\
\hline 2003 & 351 & 369 & 518 & 384 & 417 & 479 & 642 & 395 & 579 & 617 \\
\hline 2004 & 599 & 562 & 683 & 609 & 755 & 714 & 722 & 564 & 743 & 689 \\
\hline 2005 & 577 & 411 & 664 & 473 & 655 & 733 & - & - & - & - \\
\hline 5 -yr mean & 500 & 430 & 541 & 439 & 577 & 619 & 669 & 489 & 699 & 671 \\
\hline \multirow[t]{2}{*}{ 30-yr mean } & 460 & 434 & 560 & 472 & 531 & 581 & 706 & 627 & 779 & 679 \\
\hline & \multicolumn{10}{|c|}{ Temperature $\left({ }^{\circ} \mathrm{C}\right)$} \\
\hline 2000 & - & - & - & - & - & - & 9.2 & 10.3 & 11.1 & 12.8 \\
\hline 2001 & 3.3 & 5.3 & 7.2 & 7.9 & 7.7 & 8.2 & 9.4 & 10.3 & 11.2 & 12.6 \\
\hline 2002 & 2.5 & 4.7 & 7.3 & 8.2 & 8.3 & 8.7 & 9.4 & 10.3 & 11.3 & 12.6 \\
\hline 2003 & 2.6 & 4.3 & 6.9 & 7.9 & 7.8 & 8.9 & 9.1 & 10.2 & 10.7 & 12.1 \\
\hline 2004 & 1.9 & 4.2 & 7.0 & 7.6 & 8.1 & 9.2 & 9.2 & 10.3 & 10.7 & 11.9 \\
\hline 2005 & 3.3 & 5.3 & 6.7 & 8.0 & 8.7 & 9.8 & - & - & - & - \\
\hline 5-yr mean & 2.7 & 4.8 & 7.0 & 7.9 & 7.7 & 8.2 & 9.2 & 10.3 & 11.1 & 12.8 \\
\hline 30-yr mean & 3.6 & 4.3 & 6.1 & 6.5 & 7.4 & 7.9 & 8.8 & 9.1 & 10.3 & 11.4 \\
\hline
\end{tabular}

\section{Statistical Analysis}

The study was a repeated measure experiment with stand age (Establishment year through year 5) and location as a fixed effect while year (2000 through 2005) was considered a random effect to differentiate between the normal stand maturation trend over time and random weather effects [19]. The likelihood ratio test was used to determine the significance of the random variable year [18]. Harvest year was treated as a numerical variable to determine the yield and switchgrass stand trends over time. Data were analyzed using the mixed procedure in SAS [18]. The appropriate correlation structure was used that produced the smallest Akaike Information Criterion statistic [19].

Correlations were determined using Pearson's correlation coefficient procedures between topographic effects, biomass yield and stand frequency. Each location had 16 quadrat sites where yield and stand measurements were repeatedly taken each year. Biomass yield data for each quadrat was correlated with slope, aspect, elevation, and curvature data within each location to test for relationships of these variables with biomass yield, using Pearson product-moment correlation coefficients. Slope, aspect, elevation, and curvature values for each quadrat site by location were determined by digital elevation models described above. Topographic comparisons were evaluated separately by location and harvest year. Multiple switchgrass cultivars were planted in Lawrence, Douglas, and Crofton [25]. However, overall yield $(p=0.16)$ and stand frequency means $(p=0.18)$ by cultivar were not significantly different within locations. Yield and stand frequency results that were from cultivars nested within location were pooled together and treated as a single unit.

\section{Temporal Variation}

Whelan and McBratney [35] evaluated field crop yield variation using temporal variances to compare within-field spatial variances. The temporal variance equation used:

$\sigma_{i}^{2}=\frac{\sum_{h=3}^{n}\left(Y i, h-\bar{Y}_{i}\right)^{2}}{n-1}$

where $\sigma_{i}^{2}$ is the temporal variance at point $i, Y_{i, h}$ is switchgrass yield at quadrat site $i$ at harvest year $h, \overline{Y_{i}}$ is switchgrass mean yield from quadrat site $i$ for all selected harvest years, and $n$ is the number of harvest years. Temporal variances were estimated using growing season three to five to measure yield in fully mature switchgrass stands. The square root of the temporal variance $\left(\sigma_{i}^{2}\right)$ gives the standard deviation for each quadrat site.

Equation a can give both a mean temporal variance value and a temporal variance value for each quadrat site. Results from Eq. a can be evaluated further to identify within-field quadrat sites that are (i) higher yielding areas than the field mean and with low temporal stand deviations, (ii) lower yielding areas than the field mean with low temporal 
standard deviations, (iii) higher yielding areas than the field mean with high temporal standard deviations, and (iv) lower yielding areas than the field mean with high temporal standard deviations [4].

\section{Results}

Locations were particularly warm and dry during the establishment year. All locations with the exception of Munich, ND had above average temperatures compared to the 30-yr mean for the duration of the study (Table 2). Douglas, Atkinson, Highmore, Bristol, and Streeter locations had temperatures $10 \%$ above normal (Table 2). Locations with the exception of Ethan, Huron, and Munich had below average precipitation for the duration of the study. In 2002, weather conditions were particularly warm and dry resulting in low switchgrass mean yields (Table 3).

\section{Biomass Yield}

Location differences were significant for biomass yield which followed a quadratic relationship over time (Table 4). The location by harvest year interaction was not significant (Table 4). The random effect of year (weather effects) was significant for switchgrass yield using the likelihood ratio test $(p<0.05)$. Highest yields for all locations occurred in 2003 and 2004. Biomass yields declined in 2005 from 2004 values likely because of weather factors, reduced nitrogen applications by cooperating farmers, or a combination of weather and nitrogen rate applications. (Table 1). Standard deviations within-locations tended to be lower than stan-
Table 4 Significance levels of biomass yield and stand frequency field means by location and harvest year at 10 switchgrass fields in Nebraska, South Dakota, and North Dakota grown for bioenergy

\begin{tabular}{llll}
\hline Source of variation & df & Yield & Stand frequency \\
\hline Location (L) & 9 & $* * *$ & $* * *$ \\
Harvest Year (HY) & 1 & $*$ & $* * *$ \\
$\mathrm{HY}^{2}$ & 1 & $* *$ & $* *$ \\
$\mathrm{~L} * \mathrm{HY}$ & 9 & $\mathrm{NS}$ & $* *$ \\
$\mathrm{~L}^{*} \mathrm{HY}^{2}$ & 9 & $\mathrm{NS}$ & $* *$ \\
\hline
\end{tabular}

$*, * *, * * *$, Significant at the $0.05,0.01$ and 0.001 probability levels, respectively.

dard deviations across locations and years for biomass yield.

Locations tended to have consistent spatial standard deviation means throughout the study even though overall yield means varied across harvest years because of either weather conditions or stand maturation. The relationship between spatial standard deviation and biomass yield was constant with $\left(b_{1}=0\right)$ for all but two locations (Fig. 2). Slopes $\left(b_{1}\right)$ that were not equal to zero, Highmore and Atkinson, showed increased spatial standard deviations with increased switchgrass yields.

Six out of the ten switchgrass fields showed a significant, positive trend between temporal standard deviations and quadrat site mean yields for locations in growing season three through five (Fig. 3). For locations that showed a significant trend, quadrat sites that had higher switchgrass yields also were the least stable in terms of temporal standard deviation. Quadrat sites with lower switchgrass yields than the field mean had lower standard

Table 3 Average dry matter (DM) within field quadrat yield $(n=16)$ by location and year for switchgrass fields managed for bioenergy production in the Great Plains

\begin{tabular}{|c|c|c|c|c|c|c|c|c|c|c|}
\hline Year & $\begin{array}{l}\text { Munich } \\
\text { Biomass }\end{array}$ & $\begin{array}{l}\text { Streeter } \\
\text { ield }(\mathrm{Mg} \mathrm{l}\end{array}$ & $\begin{array}{l}\text { Bristol } \\
-1 \text { ) }\end{array}$ & Highmore & Huron & Ethan & Crofton & Atkinson & Douglas & Lawrence \\
\hline 2000 & - & - & - & - & - & - & $3.0 \pm 1.7^{\mathrm{a}}$ & - & $4.9 \pm 2.2$ & $2.9 \pm 1.8$ \\
\hline 2001 & $2.5 \pm 2.3$ & $\mathrm{~b}$ & $7.4 \pm 4.0$ & $2.2 \pm 0.7$ & $4.4 \pm 1.2$ & $4.4 \pm 1.0$ & $4.6 \pm 1.1$ & $3.5 \pm 1.2$ & $6.9 \pm 2.6$ & $4.5 \pm 2.0$ \\
\hline 2002 & $4.6 \pm 1.3$ & $4.6 \pm 1.1$ & $7.3 \pm 1.8$ & $1.1 \pm 0.7$ & $4.9 \pm 1.3$ & $2.4 \pm 0.9$ & $5.0 \pm 1.2$ & $1.5 \pm 0.7$ & $6.7 \pm 2.5$ & $5.4 \pm 1.5$ \\
\hline 2003 & $9.8 \pm 2.2$ & $5.9 \pm 1.1$ & $12.0 \pm 1.6$ & $6.6 \pm 1.9$ & $\mathrm{c}$ & $7.9 \pm 1.5$ & $6.6 \pm 2.5$ & $7.3 \pm 2.3$ & $9.0 \pm 1.6$ & $8.1 \pm 1.9$ \\
\hline 2004 & $5.6 \pm 0.9$ & $7.4 \pm 1.4$ & $9.6 \pm 2.0$ & $8.5 \pm 3.1$ & $8.7 \pm 1.5$ & $5.8 \pm 1.9$ & $7.3 \pm 1.3$ & $7.5 \pm 2.0$ & $9.3 \pm 2.1$ & $5.9 \pm 1.4$ \\
\hline 2005 & $6.4 \pm 2.2$ & $4.6 \pm 1.2$ & $7.7 \pm 1.6$ & $2.8 \pm 0.6$ & $4.5 \pm 0.6$ & $4.9 \pm 1.3$ & - & d & - & - \\
\hline Post-estab. mean ${ }^{\mathrm{e}}$ & $7.3 \pm 2.6$ & $6.0 \pm 1.6$ & $9.8 \pm 2.4$ & $6.0 \pm 3.1$ & $6.6 \pm 2.9$ & $6.2 \pm 1.9$ & $6.3 \pm 1.7$ & $7.4 \pm 1.6$ & $8.3 \pm 2.1$ & $6.5 \pm 1.7$ \\
\hline 5 -yr mean & $5.8 \pm 3.0$ & $5.6 \pm 1.6$ & $8.8 \pm 3.0$ & $4.2 \pm 3.3$ & $5.6 \pm 2.1$ & $5.3 \pm 2.4$ & $5.3 \pm 2.2$ & $5.0 \pm 3.0$ & $7.4 \pm 2.7$ & $5.4 \pm 2.4$ \\
\hline
\end{tabular}

${ }^{\text {a }}$ Standard deviation

${ }^{\mathrm{b}}$ Mechanical hay harvest was done in mid-summer to remove volunteer oats

${ }^{\mathrm{c}}$ Mechanical hay harvest was done prior to quadrat yield sampling

${ }^{\mathrm{d}}$ Study completed at end of harvest year four

${ }^{\mathrm{e}}$ Post-establishment mean switchgrass yield from growing season year 3 to growing season year 5. 


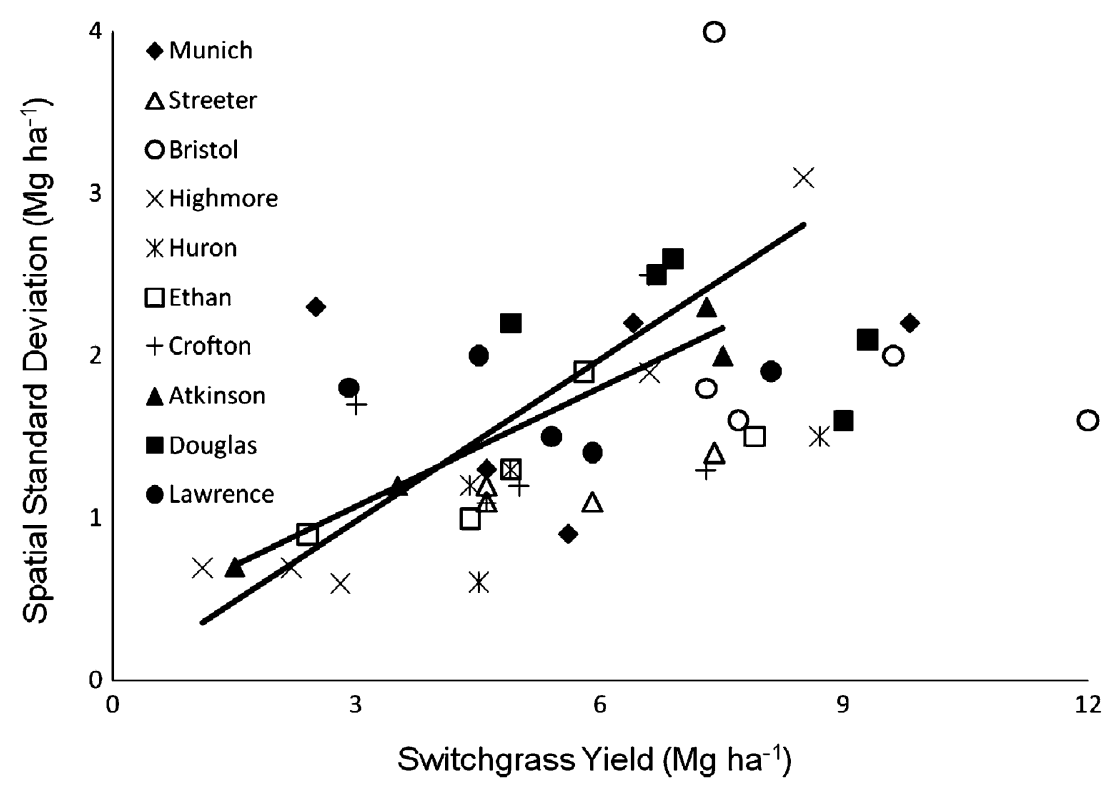

Fig. 2 Relationship between switchgrass yield and spatial standard deviation at each location from the establishment year to growing season year five on switchgrass fields managed for bioenergy.

deviations than higher yielding quadrat sites resulting in higher temporal stability. Areas within fields that were above the switchgrass field mean had a larger yield response to highly variable weather conditions than quadrat sites with below average switchgrass yields. The North Dakota and South Dakota locations showed higher temporal standard deviations than spatial standard deviations on established switchgrass fields (Table 3). The Nebraska locations each had one year where spatial standard deviations were equal to or greater than the temporal standard deviation (Table 3). The temporal standard deviation for most locations was higher than the spatial standard deviation for a given year, but considerable temporal standard deviation differences between quadrat sites would indicate that identifying management zones within a field may be possible if sites are spatially distinct.

Topographic effects on switchgrass biomass yields by location and year did not explain yield variability (Table 5). Slope did not significantly impact biomass yield with the exception of the Douglas and Lawrence locations for one growing season each. Switchgrass yield declined as slope increased at Lawrence whereas yield increased with increasing slope at Douglas. Switchgrass yield was negatively correlated with north facing topographic positions for one year at Highmore and two consecutive years at Lawrence while positively correlated with north facing topographic positions for one year at Crofton (Table 5). Lawrence showed a negative response to north facing topographic positions in subsequent years while Crofton showed a positive response to north facing topographic positions in 2003 (Table 5). Switchgrass yield increased as
Highmore $\left(r^{2}=0.92\right)$ and Atkinson $\left(r^{2}=0.96\right)$ were the only locations that had a significant linear relationship $(P \leq 0.05)$ between spatial standard deviation and switchgrass yield

elevation increased at Streeter, Highmore, Ethan, and Lawrence while switchgrass biomass yields decreased with elevation at Munich for one growing season (Table 5). Switchgrass yields increased with increased elevation at Lawrence in 2002. In 2004, switchgrass yield was positively correlated with elevation at Highmore, Ethan, and Lawrence and negatively correlated at Munich (Table 5). Highmore which showed a positive trend between spatial standard deviations and switchgrass yield had a positive correlation in 2004 with elevation, the same year when the spatial standard deviation was the largest (Tables 3 and 5). Quadrat sites with convex surfaces were positively correlated with switchgrass yield at Munich, Streeter, Highmore, Huron, Ethan, and Lawrence for a single growing season. Switchgrass yields were higher in quadrat sites with concave surfaces for two growing seasons at Crofton and a single growing season at Douglas (Table 7).

\section{Stand Frequency}

Overall, switchgrass stands increased in frequency by $57 \%$ from the establishment year to harvest year five (Table 6). The initial difference between switchgrass stands across locations decreased by harvest year five for locations established in 2000 and 2001 (Table 6). All locations had stand frequencies above $50 \%$ by season three with the exception of Munich, ND which did not reach a stand frequency of $50 \%$ by season five. The Munich location had the lowest initial stand frequency of all locations but stand frequencies did increase by $261 \%$ from the establishment year to harvest year five (Table 6). 

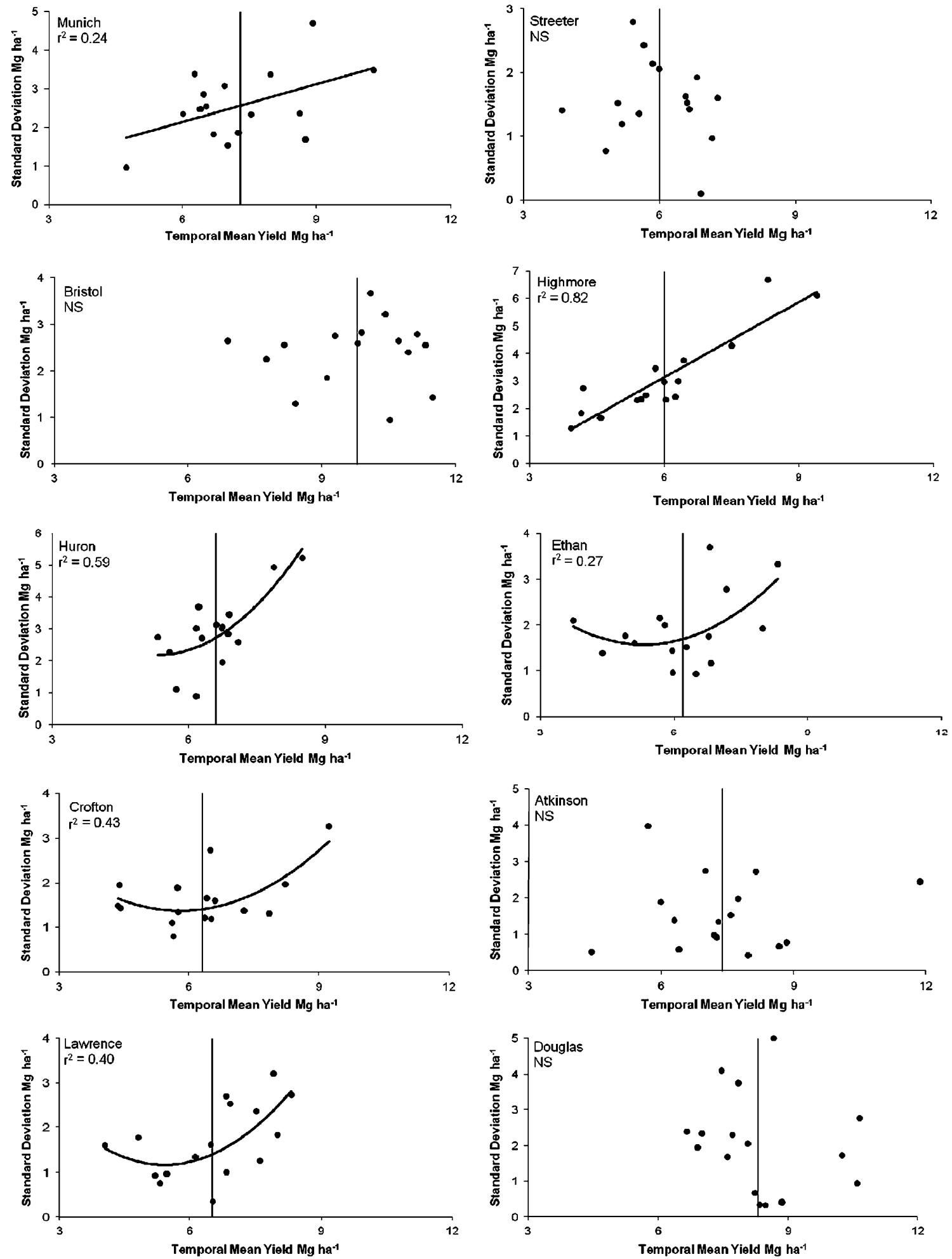

Fig. 3 Relationship between temporal standard deviation and temporal mean yield at each within-field quadrat site $(n=16)$ for ten switchgrass fields in North Dakota, South Dakota, and Nebraska from growing season three to growing season five. Vertical lines correspond

to field mean yields from quadrat sampling. Significant relationships and corresponding coefficients of determination are presented at $P \leq 0.05$ 
Table 5 Topographic effects on switchgrass quadrat yield from fields in the Great Plains using Pearson's correlation coefficient.

\begin{tabular}{|c|c|c|c|c|c|c|c|c|c|c|}
\hline & Munich & Streeter & Bristol & Highmore & Huron & Ethan & Crofton & Atkinson & Douglas & Lawrence \\
\hline Year & Slope & & & & & & & & & \\
\hline 2000 & & & & & & & NS & & NS & NS \\
\hline 2001 & NS & NS & NS & NS & NS & NS & NS & NS & NS & NS \\
\hline 2002 & NS & NS & NS & NS & NS & NS & NS & NS & NS & $-0.43^{\mathrm{a}}$ \\
\hline 2003 & NS & NS & NS & NS & - & NS & NS & NS & $0.88^{\mathrm{c}}$ & NS \\
\hline 2004 & NS & NS & NS & NS & NS & NS & NS & NS & NS & NS \\
\hline 2005 & $\begin{array}{l}\text { NS } \\
\text { Aspect }\end{array}$ & NS & NS & NS & NS & NS & & - & & \\
\hline 2000 & & & & & & & NS & & NS & NS \\
\hline 2001 & NS & NS & NS & NS & NS & NS & NS & NS & NS & NS \\
\hline 2002 & NS & NS & NS & NS & NS & NS & NS & NS & NS & $-0.59^{b}$ \\
\hline 2003 & NS & NS & NS & $-0.70^{\mathrm{c}}$ & - & NS & $0.45^{\mathrm{a}}$ & NS & NS & $-0.59^{\mathrm{b}}$ \\
\hline 2004 & NS & NS & NS & NS & NS & NS & NS & NS & NS & NS \\
\hline 2005 & $\begin{array}{l}\text { NS } \\
\text { Elevation }\end{array}$ & NS & NS & NS & NS & NS & & - & & \\
\hline 2000 & & & & & & & NS & & NS & NS \\
\hline 2001 & NS & NS & NS & NS & NS & NS & NS & NS & NS & NS \\
\hline 2002 & NS & NS & NS & NS & NS & NS & NS & NS & NS & $0.64^{\mathrm{c}}$ \\
\hline 2003 & NS & NS & NS & NS & - & NS & NS & NS & NS & NS \\
\hline 2004 & $-0.62^{\mathrm{c}}$ & NS & NS & $0.59^{\mathrm{b}}$ & NS & $0.62^{\mathrm{b}}$ & NS & NS & NS & 0.44 \\
\hline 2005 & $\begin{array}{l}\text { NS } \\
\text { Curvature }\end{array}$ & $0.52^{\mathrm{b}}$ & NS & NS & NS & NS & & - & & \\
\hline 2000 & & & & & & & NS & & NS & NS \\
\hline 2001 & NS & NS & NS & $0.66^{\mathrm{c}}$ & $0.58^{\mathrm{b}}$ & NS & NS & NS & NS & $0.47^{\mathrm{b}}$ \\
\hline 2002 & $0.55^{\mathrm{b}}$ & NS & NS & NS & NS & NS & $-0.43^{\mathrm{a}}$ & NS & $-0.48^{\mathrm{a}}$ & NS \\
\hline 2003 & NS & NS & NS & NS & - & NS & $-0.55^{\mathrm{b}}$ & NS & NS & NS \\
\hline 2004 & NS & $0.60^{\mathrm{b}}$ & NS & NS & NS & NS & NS & NS & NS & NS \\
\hline 2005 & NS & NS & NS & NS & NS & $0.74^{\mathrm{c}}$ & & - & & \\
\hline
\end{tabular}

${ }^{\mathrm{a}},{ }^{\mathrm{b}},{ }^{\mathrm{c}}$ Significant at the $0.1,0.05$, and 0.01 probability levels, respectively

Table 6 Average stand frequency by location and year for switchgrass fields managed for bioenergy production in the Great Plains

\begin{tabular}{|c|c|c|c|c|c|c|c|c|c|c|}
\hline & Munich & Streeter & Bristol & Highmore & Huron & Ethan & Crofton & Atkinson & Douglas & Lawrence \\
\hline Year & \multicolumn{10}{|c|}{ Stand Frequency (\%) } \\
\hline 2000 & - & - & - & - & - & - & $50 \pm 17^{\mathrm{a}}$ & - & $48 \pm 13$ & $39 \pm 14$ \\
\hline 2001 & $13 \pm 14$ & $22 \pm 17$ & $45 \pm 6$ & $61 \pm 14$ & $92 \pm 7$ & $23 \pm 16$ & $45 \pm 17$ & $42 \pm 30$ & $37 \pm 15$ & $55 \pm 24$ \\
\hline 2002 & $30 \pm 19$ & $41 \pm 19$ & $59 \pm 9$ & $51 \pm 17$ & $80 \pm 11$ & $62 \pm 21$ & $68 \pm 14$ & $73 \pm 21$ & $56 \pm 19$ & $65 \pm 16$ \\
\hline 2003 & $46 \pm 23$ & $72 \pm 22$ & $70 \pm 6$ & $80 \pm 11$ & $92 \pm 6$ & $89 \pm 7$ & $70 \pm 12$ & $84 \pm 14$ & $69 \pm 21$ & $78 \pm 14$ \\
\hline 2004 & $45 \pm 13$ & $72 \pm 20$ & $67 \pm 6$ & $72 \pm 16$ & $83 \pm 7$ & $86 \pm 11$ & $80 \pm 8$ & $89 \pm 8$ & $80 \pm 7$ & $77 \pm 9$ \\
\hline 2005 & $47 \pm 14$ & $53 \pm 26$ & $63 \pm 9$ & $61 \pm 24$ & $86 \pm 10$ & $80 \pm 20$ & - & $\mathrm{b}$ & - & - \\
\hline Post-estab. mean ${ }^{c}$ & $46 \pm 14$ & $66 \pm 20$ & $67 \pm 8$ & $71 \pm 16$ & $87 \pm 9$ & $85 \pm 12$ & $73 \pm 11$ & $82 \pm 10$ & $68 \pm 19$ & $73 \pm 14$ \\
\hline 5-yr mean & $40 \pm 20$ & $56 \pm 27$ & $62 \pm 10$ & $66 \pm 20$ & $87 \pm 9$ & $74 \pm 26$ & $66 \pm 18$ & $78 \pm 22$ & $63 \pm 22$ & $67 \pm 20$ \\
\hline
\end{tabular}

${ }^{\text {a }}$ Standard deviation

${ }^{\mathrm{b}}$ Study completed at end of harvest year four

${ }^{\mathrm{c}}$ Post-establishment mean switchgrass yield from growing season year 3 to growing season year 5 
There was a significant quadratic harvest year $\mathrm{x}$ location interaction for switchgrass stand frequency (Table 4). The random variance component year (weather effects) was non-significant $(p \leq 0.05)$ suggesting weather effects have less effect on switchgrass stand response than switchgrass yield. Spatial stand deviations tended to decline as switchgrass stands matured over the study period.

Seven of the ten locations showed a significant, negative trend between temporal stand variability and switchgrass quadrat site stand frequency (Fig. 4). Locations that showed a significant trend had lower temporal standard deviations for quadrat site with high switchgrass stand frequencies while quadrat sites with lower than average switchgrass stand frequencies had higher temporal standard deviations. Areas within fields that have high stand frequencies are relatively more stable over time than areas with low stand frequencies. Locations that did not show a significant trend over time had quadrat sites that were relatively stable over time while other quadrat sites were unstable over time regardless of the overall quadrat site stand frequency mean (Fig. 4). Areas within fields that display switchgrass stand frequency stability over time will likely result in predictable stand frequencies in the future regardless of weather conditions. The temporal and spatial standard deviations for stand frequency at growing seasons three to five were similar for most locations.

Topographic effects did not appear to influence switchgrass stand frequencies. Slope effects on switchgrass stand frequency across locations and years were significant $8 \%$ of the time while aspect and elevation were significant $14 \%$ and $16 \%$ of the time, respectively (Table 7). Stand frequency increased with increasing slope at Douglas, whereas stand frequency decreased with increasing slope in the establishment year at Highmore. At Lawrence, stand frequency decreased with increasing slope in 2003 but increased with increasing slope in 2004 (Table 7). Switchgrass stand frequency had a positive response to north facing aspects at five locations in each growing season but higher stand frequencies to south facing aspects at Highmore in 2003 and 2005 (Table 7). Elevation was positively correlated with greater switchgrass stand frequencies at Huron and Lawrence for two out of the five growing seasons and was negatively correlated at Streeter, Atkinson, and Douglas (Table 7). The response to switchgrass stands with respect to curvature was variable by location. Stand frequencies at Streeter, Ethan, and Crofton showed a positive correlation to quadrat sites with more convex surfaces while Highmore, Atkinson, and Douglas showed higher stand frequencies on concave surfaces. There were no discernable trends between switchgrass stands and topographic effects across locations or by year.

\section{Discussion}

Below normal precipitation was a major factor during the study period at most locations, particularly in 2002, which caused lower than expected switchgrass yields. A similar switchgrass yield response caused by below normal precipitation occurred on small-scale switchgrass plots within the same region [3, 16, 22]. Switchgrass is a likely bioenergy crop on rain-fed, marginal cropland within the U.S. The effect of weather conditions on switchgrass yield or other dedicated perennial bioenergy crops will impact the amount of biomass available within a region. Knowledge of temporal yield variation from switchgrass stand development across years and weather contributions to yield variation will be critical in establishing reliable feedstock supply areas for a cellulosic biorefinery [12]. The results of this study indicate that field scale biomass yield is acceptable for use in modeling feedstock supply in this major agroecoregion because of consistent spatial variability over time among locations.

Comparing temporal standard deviation and mean biomass yield has been used to measure ecological stability within synthetic grassland plots [26] and in annual row crop fields $[4,35]$. Fields with high temporal variances and low spatial variances would indicate a uniform field where management decisions would be prescribed for the entire field [35]. Spatial variability was consistent over time for most locations with the exception of the Highmore and Atkinson locations, which had a trend of increasing spatial variability with increasing switchgrass yield. These field locations were in the western most part of the study where precipitation was the most variable suggesting that within field yield variation will be more variable in regions where precipitation has greater fluctuations. Temporal variances were similar to spatial variances for most locations once switchgrass was fully established. The majority of switchgrass fields showed a similar trend with decreased yield stability on quadrat sites with above average yields and increased temporal stability on quadrat sites with below average yields. Quadrat sites with better yield potential likely had a greater response to favorable weather conditions than quadrat sites with lower yield potential leading to greater temporal variation.

Previous spatial variation research has been done in small plots or fields and not across major agroecoregions, but the results of those studies are generally consistent with the results of this study. Switchgrass plots in Southern Iowa showed few yield differences by landscape position [7] although in one of two harvest years, yields on summits were higher than on backslope or footslope topographic positions [7]. Virgilio et al. [29] found a negative relationship between slope and switchgrass biomass yield for two years on a 4.8 ha field in Northern Italy. 

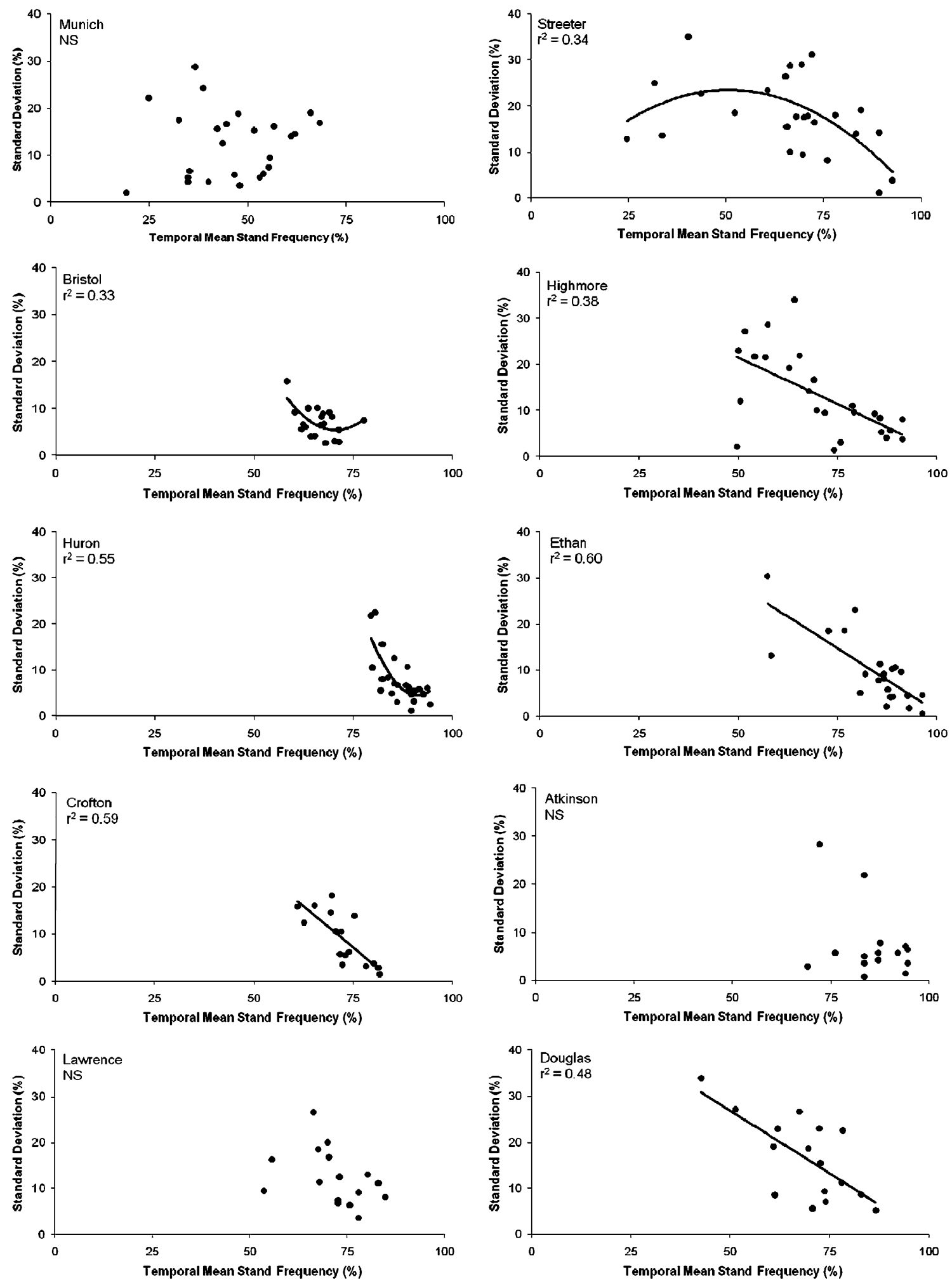

Fig. 4 Relationship between temporal standard deviation and temporal stand frequency at each within-field quadrat site $(n=18$ to 25$)$ for ten switchgrass fields in North Dakota, South Dakota, and Nebraska

from growing season three to growing season five. Significant relationships and corresponding coefficients of determination are presented at $P \leq 0.05$ 
Table 7 Topographic effects on stand frequency from switchgrass fields in the Great Plains using Pearson's correlation coefficient

\begin{tabular}{|c|c|c|c|c|c|c|c|c|c|c|}
\hline & Munich & Streeter & Bristol & Highmore & Huron & Ethan & Crofton & Atkinson & Douglas & Lawrence \\
\hline Year & Slope & & & & & & & & & \\
\hline 2000 & & & & & & & NS & & NS & NS \\
\hline 2001 & NS & NS & NS & $-0.53^{\mathrm{a}}$ & NS & NS & NS & NS & NS & NS \\
\hline 2002 & NS & NS & NS & NS & NS & NS & NS & NS & $0.55^{\mathrm{b}}$ & NS \\
\hline 2003 & NS & NS & NS & NS & - & NS & NS & NS & NS & $-0.45^{\mathrm{b}}$ \\
\hline 2004 & NS & NS & NS & NS & NS & NS & NS & NS & NS & $0.34^{\mathrm{a}}$ \\
\hline 2005 & $\begin{array}{l}\text { NS } \\
\text { Aspect }\end{array}$ & NS & NS & NS & NS & NS & & & & \\
\hline 2000 & & & & & & & NS & & NS & NS \\
\hline 2001 & NS & NS & NS & NS & $-0.56^{\mathrm{a}}$ & NS & NS & NS & NS & NS \\
\hline 2002 & NS & NS & NS & NS & NS & $-0.46^{\mathrm{a}}$ & NS & NS & NS & NS \\
\hline 2003 & NS & NS & NS & $0.42^{\mathrm{b}}$ & NS & NS & $-0.47^{\mathrm{b}}$ & NS & NS & NS \\
\hline 2004 & NS & NS & NS & NS & NS & NS & NS & NS & $-0.43^{\mathrm{b}}$ & NS \\
\hline 2005 & $\begin{array}{l}\text { NS } \\
\text { Elevation }\end{array}$ & NS & $-0.39^{\mathrm{a}}$ & $0.58^{\mathrm{c}}$ & NS & NS & & & & \\
\hline 2000 & & & & & & & NS & & NS & NS \\
\hline 2001 & NS & NS & NS & NS & NS & NS & NS & NS & NS & $0.54^{\mathrm{a}}$ \\
\hline 2002 & NS & NS & NS & NS & $0.50^{\mathrm{b}}$ & NS & NS & $-0.52^{\mathrm{b}}$ & NS & NS \\
\hline 2003 & NS & $-0.48^{\mathrm{b}}$ & NS & NS & NS & NS & NS & NS & NS & $0.43^{\mathrm{b}}$ \\
\hline 2004 & NS & NS & NS & NS & NS & NS & NS & NS & $-0.42^{\mathrm{b}}$ & NS \\
\hline 2005 & $\begin{array}{l}\text { NS } \\
\text { Curvature }\end{array}$ & $-0.36^{\mathrm{a}}$ & NS & NS & $0.41^{\mathrm{b}}$ & NS & & & & \\
\hline 2000 & & & & & & & NS & & NS & NS \\
\hline 2001 & NS & NS & NS & NS & NS & $0.52^{\mathrm{a}}$ & $0.66^{\mathrm{b}}$ & NS & $-0.53^{\mathrm{a}}$ & NS \\
\hline 2002 & NS & NS & NS & $-0.43^{\mathrm{a}}$ & NS & $0.45^{\mathrm{a}}$ & NS & $-0.61^{\mathrm{b}}$ & NS & NS \\
\hline 2003 & NS & NS & NS & NS & NS & NS & NS & NS & NS & NS \\
\hline 2004 & NS & $0.43^{\mathrm{b}}$ & NS & NS & NS & NS & NS & NS & NS & NS \\
\hline 2005 & NS & NS & NS & NS & NS & $0.41^{\mathrm{a}}$ & & & & \\
\hline
\end{tabular}

a $,{ }^{b},{ }^{c}$ Significant at the $0.1,0.05$, and 0.01 probability levels, respectively

Switchgrass yield response to aspect position was found to be significant in one out of two years [29]. In contrast, negative correlations were commonly found between elevation and corn and soybean yields under highly variable weather conditions [15] whereas elevation effects were not correlated for corn and soybean yield under normal weather conditions [12]. Water availability is the probable result of yield differences by elevation in annual cropping systems. The general lack of response to elevation and switchgrass yield, unlike annual cropping systems, is likely the cause of a fully established root system that is able to utilize water resources more efficiently throughout the growing season. In 2002, when drought conditions were prevalent in the study region, elevation was not a critical factor in switchgrass yield with the exception of the Lawrence location. Soil parameters of soil N, pH, soil P, and soil moisture explained more of the switchgrass yield variation than topographic effects in Italy [29]. Soil properties explained $30 \%$ of the overall yield variability for fields grown in corn and soybeans [15]. Intensive spatial soil sampling was not conducted from these fields but soil parameters will probably contribute more to switchgrass yield variation than topographic effects. Partitioning fields into management zones based on topographic characteristics through the use of geographic information systems and precision agriculture technology for site specific management inputs does not appear to be warranted with existing switchgrass cultivars.

Initial switchgrass stand frequency varied by locations, a result of weather conditions, field equipment and cooperator management practices [25]. Switchgrass stand survival appears to be affected mostly by cultivar winter hardiness tolerance [3] or by harvest date [8]. Switchgrass stands for most locations showed high temporal stability (low temporal standard deviation) in quadrat sites with high stand frequency while lower stand 
frequencies showed lower temporal stability (high temporal standard deviation). At the end of this study, switchgrass stand frequencies were similar to small plot switchgrass stands [3, 16]. Switchgrass stands tend to increase or self- thin over time until a stand equilibrium is reached which varies with site. In this study field scale stand frequency at the end of five years ranged from approximately $50-80 \%$ (Table 6). Stand frequencies greater than $50 \%$ are considered to be fully successful (Vogel and Masters, 2001). The capability of switchgrass plants to produce short rhizomes enables stands frequencies to be relatively stable over time and does not appear to be greatly affected by topographic factors. Ensuring successful, high switchgrass stands can be done by planting at the appropriate time of year, using appropriate seeding equipment, using quality seed, and proper weed control.

Monitoring switchgrass stands in late spring is critical in the establishment year to assess initial stand success and to prescribe potential herbicide treatments for weed control. The stand frequency grid in conjunction with a GPS receiver in the establishment year enables the identification of within-field areas having low switchgrass stands $(<25 \%)$ that would require partial reseeding. The stand frequency grid to monitor weed populations with a GPS receiver could be used to identify regions that require spot herbicide treatments or identify field herbicide treatments based on overall weed populations. Based on this study, when switchgrass fields have reached full yield potential (one to two years after planting) the need to annually monitor switchgrass stands is not critical due to an increase in stand frequency and increased stand stability. Stand frequency measurements would still be useful to monitor fields where weed populations persist.

Sampling protocols to estimate switchgrass biomass yield will need to be developed for producers, government agencies, and biorefinery companies to ensure adequate supplies and profitability. Clipped quadrats are effective in estimating biomass yield and standard deviation but more efficient sampling methods with similar precision are warranted. The use of indirect measurements may provide a more efficient method to estimate switchgrass biomass at the field-scale.

In the Northern Great Plains agroecoregion, there is greater temporal and spatial variation for switchgrass biomass yields among fields than within fields. As a result modeling switchgrass biomass yields for feedstock availability for biorefineries can be completed using mean field yields. Within field site specific management and application of management inputs for switchgrass grown as a biomass energy crop in this region is not warranted with existing cultivars but may be valuable in the future when higher yielding plant materials will be available for commercial use.

\section{References}

1. Abrams MD, Knapp AK, Hulbert LC (1986) A ten-year record of aboveground biomass in a Kansas tallgrass prairie: effects of fire and topographic position. Am J Bot 73:1509-1515

2. Ayyad MG, Dix RL (1964) An analysis of a vegetationmicroenvironmental complex on prairie slopes in Saskatchewan. Ecol Monogr 34:421-442

3. Berdahl JD, Frank AB, Krupinsky JM, Carr PM, Hanson JD, Johnson HA (2005) Biomass yield, phenology, and survival of diverse switchgrass cultivars and experimental strains in Western North Dakota. Agron J 97:549-555

4. Blackmore S, Godwin RJ, Fountas S (2003) The analysis of spatial and temporal trends in yield map data over six years. Biosyst Eng 84:455-466

5. Briggs JM, Knapp AK (1995) Interannual variability in primary production in tallgrass prairie: climate, soil moisture, topographic position, and fire as determinants of aboveground biomass. Am J Bot 82:1024-1030

6. Brummer JE, Nichols JT, Engel RE, Eskridge KM (1994) Efficiency of different quadrat sizes and shapes for sampling standing crop. J Range Manage 47:84-89

7. Brummer EC, CL Burras, MD Duffy, KJ Moore (2000) Switchgrass production in Iowa: economic analysis, soil suitability and varietal performance. Tech. Report Bioenergy feedstock development program. Oak Ridge, TN

8. Casler MD, Boe AR (2003) Cultivar x environment interactions in switchgrass. Crop Sci 43:2226-2233

9. Casler MD, Vogel KP, Taliaferro CM, Wynia RL (2004) Latitudinal adaptation of switchgrass populations. Crop Sci 44:293-303

10. Casler MD, Vogel KP, Taliaferro CM, Ehlke NJ, Berdahl JD, Brummer EC et al (2007) Latitudinal and longitudinal adaptation of switchgrass populations. Crop Sci 47:2249-2260

11. Fargione J, Hill J, Tilman D, Polasky S, Hawthorne P (2008) Land clearing and the biofuel carbon debt. Science 319:12351238

12. Graham RL (2007) Forecasting the magnitude of sustainable biofeedstock supplies: the challenges and rewards. Biofuels Bioprod Bioref 1:255-263

13. Jiang P, Thelen KD (2004) Effect of soil and topographic properties on crop yields in a north-central corn-soybean cropping system. Agron J 96:252-258

14. Jordan N, Boody G, Broussard W, Glover JD, Keeney D, McCown BH et al (2007) Sustainable development of the agricultural bio-economy. Science 316:1570-1571

15. Kravchenko AN, Bullock DG (2000) Correlation of corn and soybean grain yield with topography and soil properties. Agron J 92:75-83

16. Lee DK, Boe A (2005) Biomass production of switchgrass in central South Dakota. Crop Sci 45:2583-2590

17. Liebig MA, Schmer MR, Vogel KP, Mitchell RB (2008) Soil carbon storage by switchgrass grown for bioenergy. Bioenerg Res $1: 215-222$

18. Littell RC, Milliken GA, Stroup WW, Wolfinger RD (1996) SAS system for mixed models. SAS Inst Inc, Cary, NC

19. Loughin TM (2006) Improved experimental design and analysis for long-term experiments. Crop Sci 46:2492-2502

20. McLaughlin SB, De La Torre Ugarte Jr DG, Garten CT, Lynd LR, Sanderson MA, Tolbert VR et al (2002) High-value renewable energy from prairie grasses. Environ Sci Technol $36: 2122-2129$

21. Moore KJ, Moser LE, Vogel KP, Waller SS, Johnson BE, Pedersen JF (1991) Describing and quantifying growth stages of perennial forage grasses. Agron J 83:1073-1077 
22. Mulkey VR, Owens VN, Lee DK (2006) Management of switchgrass-dominated Conservation Reserve Program lands for biomass production in South Dakota. Crop Sci 46:712720

23. Perrin RK, Vogel KP, Schmer MR, Mitchell RB (2008) Farmscale production costs of switchgrass for biomass. Bioenerg Res 1:91-97

24. Schmer MR, Vogel KP, Mitchell RB, Perrin RK (2008) Net energy of cellulosic ethanol from switchgrass. Proc Nat Acad Sci USA 105:464-469

25. Schmer MR, Vogel KP, Mitchell RB, Moser LE, Eskridge KE, Perrin RK (2006) Establishment stand thresholds for switchgrass grown as a bioenergy crop. Crop Sci 46:157-161

26. Tilman D, Reich PB, Knops J (2006) Biodiversity and ecosystem stability in a decade-long grassland experiment. Nature 441:629 632

27. United States Congress (2007) Energy Independence and Security Act. US Government Public Law 110-140 available at http:// thomas.loc.gov/cgi-bin/bdquery/z?d110:h.r.00006

28. United States Geological Survey (2008) Digital Elevation Models. Available at http://seamless.usgs.gov/.
29. Virgilio ND, Monti A, Venturi G (2007) Spatial variability of switchgrass (Panicum virgatum L.) yield as related to soil parameters in a small field. Field Crops Res 101:232-239

30. Vogel KP, Masters RA (2001) Frequency grid - a simple tool for measuring grassland establishment. J Range Manage 54:653-655

31. Vogel KP, Brejda JJ, Walters DT, Buxton DR (2002) Switchgrass biomass production in the Midwest USA: harvest and nitrogen management. Agron J 94:413-420

32. Vogel KP (2004) Switchgrass, pp. 561-587. In: Moser LE et al. (ed) Warm-season (C4) grasses. Agron. Monogr. 45. ASA, CSSA, and SSSA, Madison, WI.

33. Walsh ME (1998) U.S. bioenergy crop economic analyses: Status and needs. Biomass Bioenergy 14:341-350

34. Walsh ME, De La Torre Ugarte DG, Shapouri H, Slinsky SP (2003) Bioenergy crop production in the United States. Environ Resour Econ 24:313-333

35. Whelan BM, McBratney AB (2000) The "null hypothesis" of precision agriculture management. Precision Agric 2:265-279

36. Wright MM, Brown RC (2007) Comparative economics of biorefineries based on the biochemical and thermochemical platforms. Biofuels Bioprod Bioref 1:49-56 